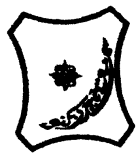

Bayero Journal of Pure and Applied Sciences, 10(2): 177 - 183

Received: December, 2017

Accepted: February, 2017

ISSN $2006-6996$

\title{
YIELD AND YIELD COMPONENTS OF INTERCROPPED DUAL-PURPOSE LABLAB AND COWPEA WITH MAIZE OF CONTRASTING MATURITIES
}

\author{
Ewansiha S.U. ${ }^{1 *}$, Chiezey U.F. ${ }^{2}$ and Law-Ogbomo K.E. ${ }^{3}$ \\ 1,3 Department of Crop Science, Faculty of Agriculture, University of Benin, Benin City, Nigeria. \\ ${ }^{2}$ Department of Agronomy, Faculty of Agriculture, Ahmadu Bello University, Zaria, Nigeria. \\ *Corresponding author: sylvester.ewansiha@uniben.edu, +2348056351478 or +2348134920763
}

\begin{abstract}
Intercropping is a way to intensify agricultural land use. Cowpea is an important crop in the traditional farming systems in northern Nigeria because it serves to provide food and feed. Although lablab has potential to function in these ways, it remains an underutilized crop because among other factors, there is dearth of information on its incorporation into the system by way of intercropping it with the major cereal crops. A field trial was conducted at Samaru $\left(11^{\circ} 11^{\prime} \mathrm{N}, 07^{\circ}\right.$ 38 'E, $686 \mathrm{~m}$ asl) in northern Guinea savannah of Nigeria, to evaluate the relative yield and yield components of dual-purpose lablab and cowpea cultivars when gown sole and when intercropped with maize of contrasting maturities. The experiment was laid out in a split-plot design with four replications. The experiment consisted of early maize maturing cultivar (TZE COMP. 5 W) and a late maize maturing cultivar (TZL COMP. 1 SYN). Cropping system (intercropping and sole cropping) was assigned to the main plot and crop cultivar (lablab: ILRI 4612, NAPRI 2 and cowpea: IT89KD288, IT99K-241-2) was assigned to subplots. Results showed that intercropping cowpea or lablab into early maturing maize cultivar was more productive than intercropping into late maturing maize cultivar for number of pods (74.4 vs. 63.9), harvest index (0.22 vs. 0.20), grain yield (575.7 vs. 441.0) and fodder yield (2075.4 vs. 1758.2) for the legumes. Lablab cultivars had superior performance than cowpea for number of pods (113.5-114.2 vs. 81.1-81.5) and fodder yield (2968.9-3042.3 vs. 1725.4-1795.9 $\mathrm{kg} \mathrm{ha}^{-1}$ ) whereas cowpea cultivars had superior performance than lablab for harvest index (0.29 vs. 0.17) and grain yield (802.3-833.9 vs. 587.8-632.4 $\mathrm{kg} \mathrm{ha}^{-1}$ ), meaning that both legumes have potential in providing food and feed with lablab producing more fodder and cowpea more grain. Land equivalent ratio showed that intercropping advantage was higher when lablab and cowpea were intercropped with early maturing maize cultivar $(1.34,1.24)$ than with late maturing maize cultivar (1.10, 1.15). It is recommended that for higher lablab or cowpea/maize productivity in an intercrop, farmers should intercrop dual-purpose cultivars of these crops with maize of earlier maturities.
\end{abstract}

Keywords: maize, lablab, cowpea, grain yield, fodder yield

\section{INTRODUCTION}

Intercropping is a way to intensify land use because more crops are grown together on the same piece of land relative to growing the staple crop as a sole crop (Ewansiha et al., 2016). Diversity demonstrates the richness of nature. Intercropping is a way to mimic nature to the benefit of mankind in food production. It is a key factor in meeting the challenge of growing more food, and combating hunger and poverty for the growing human population in the coming decades. Intercropping is practised because it often gives higher total yields and greater economic and monetary returns than the same crops grown sole. The practice also diversifies food production and household cash (Rao and Mathuva, 2000; Kimaro et al., 2009), lowers risks, and minimizes losses due to pests and diseases and losses due to adverse environmental conditions (Okigbo and Greenland, 1976; Kurata, 1986; Ofori and Stern, 1987; Altieri, 1999). Other advantages include labour complementarity, provision of more balanced human diet and efficient utilization of resources by plants of different heights, rooting systems, and nutrient requirements (Okigbo and Greenland, 1976; Willey,
1979). In particular, intercropping maize with cowpea has been observed to increase gross yield per unit area (IITA, 1983) with additional yield advantages accruing in maize under improved management (Baker, 1974). Many studies have shown advantages of legume-cereal intercropping in comparison to their sole crops in low input systems (Hauggaard-Nielsen and Jensen, 2001; Bedoussac and Justes, 2010)). In addition, cereal/cowpea intercrop was observed to promote higher productivity when maize was the cereal component than when the cereal component was either millet or sorghum (Ajeigbe et al., 2006).

Maize and cowpea are common and important crops in smallholder farming systems of northern Nigeria. In these systems, the two crops are mainly grown together for food, feed and cash. Nonetheless, cowpea and lablab are dual-purpose legumes used for food, feed and improvement of soil fertility (Ewansiha et al., 2007; IITA, 2009). While cowpea is an important component of the traditional farming systems especially in the savannah region of West Africa, lablab being an underutilized crop has not yet gain widespread popularity. 
Even though lablab has potential to make significant contributions to the farming systems of the region (Ewansiha et al., 2007), its incorporation into the system by way of intercropping it with the major cereal crops has not been widely reported. Therefore, this study was undertaken to evaluate the yielding ability of lablab relative to cowpea when grown together with maize.

\section{MATERIALS AND METHODS \\ Experimental Site}

The experiment was conducted in 2010 and 2011 cropping seasons, at the Research Farm of the Institute for Agricultural Research (IAR), Ahmadu Bello University (ABU), Samaru, Zaria $\left(11^{\circ} 11^{\prime} \mathrm{N}, 07^{\circ}\right.$ $38^{\prime} \mathrm{E}, 686 \mathrm{~m}$ asl) in the northern Guinea savannah zone of Nigeria. Samaru has an average annual rainfall of $1000 \mathrm{~mm}$ with a growing period of 151-180 days and a daily mean temperature of $20^{\circ} \mathrm{C}$ during the growing season (Jagtap, 1995). The site has leached ferruginous tropical soil having $303-400 \mathrm{~g}$ clay $/ \mathrm{kg}$ (Kowal and Kassam, 1978; Ewansiha et al., 2014a). Prior to field establishment in 2010, the soil of the experimental site was sampled, analysed by the Analytical Services Laboratory (ASLAB) of the International Institute of Tropical Agriculture (IITA), Nigeria and reportedly had $440 \mathrm{~g} \mathrm{~kg}^{-1}$ sand, $400 \mathrm{~g} \mathrm{~kg}^{-1}$ silt and $160 \mathrm{~g} \mathrm{~kg}^{-1}$ clay with organic $C$ of $5.5 \mathrm{~g} \mathrm{~kg}^{-1}$, total nitrogen $0.5 \mathrm{~g} \mathrm{~kg}^{-1}$, Mehlich $\mathrm{P} 3.41 \mathrm{ug} \mathrm{g}^{-1}, \mathrm{~K}+$ $0.23 \mathrm{cmol} \mathrm{kg}^{-1}$, and $\mathrm{pH}\left(\mathrm{H}_{2} \mathrm{O}, 1: 1\right)$ of 5.1 . The soil was vegetated mainly by Panicum maximum Jacq. Rainfall in Samaru was $930.6 \mathrm{~mm}$ in 2010 and $1127.0 \mathrm{~mm}$ in 2011. Mean daily average maximum temperature was $32^{\circ} \mathrm{C}$ with average minimum temperature of $24^{\circ} \mathrm{C}$.

Cultivars, Treatments and Experimental Design The study consisted of two maize cultivars, TZE COMP. 5 W (early maturing, 90-100 days and Striga tolerant) and TZL COMP. 1 SYN ((late-maturing, 120 days and Striga resistant); two dual-purpose lablab cultivars (ILRI 4612 and NAPRI 2) and two dualpurpose cowpea cultivars (IT89KD-288 and IT99K241-2). The treatments were cropping system (intercropping and sole cropping) and crop cultivar. The experiment was laid out in a split-plot design. Cropping system was assigned to the main plot and crop cultivar was assigned to subplots. The experiment had four replications. Sole crop of maize was added to determine land equivalent ratio. A subplot measured $3.0 \mathrm{~m} \times 5.0 \mathrm{~m}$, contained four ridges, with $75 \mathrm{~cm}$ spacing between ridges.

\section{Agronomic Practices}

Maize seeds were sown on 01 July in 2010 and 2011. For sole or intercrop, two maize seeds were sown per hole and later thinned to one plant per stand at two weeks after planting (WAP). For lablab or cowpea, seeds were sown at six weeks after maize was sown. Three seeds of lablab or cowpea were sown and later thinned to two plants per stand at two WAP. A spacing of $25 \mathrm{~cm}$ was maintained in a row for crops both in the sole crop and intercrop. One stand of lablab or cowpea was maintained between two stands of maize. At planting, $50 \mathrm{~kg} \mathrm{~N}, \mathrm{P}_{2} \mathrm{O} 5$ and $\mathrm{K}_{2} \mathrm{O}$ ha $^{-1}$, respectively, in the form of NPK 15:15:15 was applied. Urea was side-dressed at about $10 \mathrm{~cm}$ to the maize stand at a rate of $50 \mathrm{~kg} \mathrm{~N} \mathrm{ha}^{-1}$ at four WAP and covered with soil. Plots were kept weed-free using hand hoes. During vegetative, flowering and podding stages, lablab and cowpea plants were sprayed with Karate (50 g L-1 lamda-cyhalothrin, Syngenta Crop Protection AG, Basle, Switzerland) at a rate of $1.0 \mathrm{~L}$ ha ${ }^{-1}$.

\section{Measurement}

At maturity, maize plants from the two middle rows were hand-cut at the soil surface level. Maize ears were removed, sun-dried for one week, shelled and grain adjusted to $12 \%$ moisture content using Farmex MT-16 grain moisture tester. For lablab and cowpea, number of pods per unit area of $1.5 \mathrm{~m}^{2}$ within a net plot was counted at cowpea harvest. This was calculated as number of pods $\mathrm{m}^{-2}$. Harvested pods of a whole net plot were sun-dried for one week and threshed. Grains were weighed and percentage moisture content of grains was determined using Farmex MT-16 grain moisture tester. Grain yield adjusted to $14 \%$ moisture was computed from the grain. Crop residue (fodder) from a net plot were rolled up together and left on the plot to sun-dry to a constant weight. Dried fodder was weighed on the field using Salter top loading scale to obtain fodder yield per plot. This was expressed as lablab or cowpea fodder yield ha-1. Harvest index was computed for lablab and cowpea. Land equivalent ratio (LER) was calculated as a simple indicator of the biological efficiency of the intercrop system (Mead and Willey, 1980; Vandermeer, 1990).

\section{Data Analysis}

Data analysis was performed using SAS for Windows Release 9.2 (SAS Institute 2011, SAS Institute Inc., Cary, NC, USA). The SAS procedure used for the ANOVA was mixed model. Replication was treated as random effect and cropping system and crop cultivar as fixed effects in determining expected mean square and appropriate F-tests in the ANOVA. Differences between two treatment means were compared with Students t-test based on the least significant difference (LSD) at $5 \%$ level of probability.

\section{RESULTS}

\section{Number of Pods}

Year, cropping system and crop cultivar and their interactions were significant for number of pods $\mathrm{m}^{-2}$ (Table 1). Mean number of pods was $72.3 \%$ higher in 2010 than in 2011. Intercropping decreased mean number of pods: reduction was higher when legume was intercropped with late maturing maize cultivar (59\%) than with early maturing maize cultivar (52\%). Lablab cultivars had higher mean number of pods than cowpea cultivars. However, differences did not occur between lablab cultivars or cowpea cultivars for this trait. For the significant $Y \times S \times C$ interaction, when sole cropped, differences occurred among crop cultivars in 2010 but not in 2011 (Table 2). Lablab cultivar ILRI 4612 had higher number of pods than lablab cultivar NAPRI 2. 
There was no significant difference between cowpea cultivar IT89KD-288 and cowpea cultivar IT99K-2412. Lablab cultivars however, produced higher number of pods than the cowpea cultivars. When intercropped with early maturing maize cultivar, differences occurred among crop cultivars in 2010 but not in 2011. Lablab cultivars had similar number of pods; cowpea cultivars also had similar number of pods. But number of pods was higher for lablab cultivars than for cowpea cultivars. When intercropped with late maturing maize cultivar, number of pods followed the same trend as for early maturing maize cultivar in both years.

\section{Harvest Index}

With the exception of cropping system $\times$ cultivar interaction, year, cropping system and cultivar and their interactions were significant for harvest index (Table 1). Mean harvest index was 33.3\% higher in 2010 than in 2011. Intercropping decreased mean harvest index: reduction was higher when legume was intercropped with late maturing maize cultivar $(21 \%)$ than with early maturing maize cultivar $(15 \%)$. Cowpea cultivars had higher mean harvest indices than lablab cultivars. However, differences did not occur between lablab cultivars or cowpea cultivars for this trait. For the significant $\mathrm{Y} \times \mathrm{S} \times \mathrm{C}$ interaction, significant differences occurred among crop cultivars in all the cropping systems in both years (Table 3 ). When sole cropped, lablab cultivars had similar harvest index; cowpea cultivars also had similar harvest index; but cowpea cultivars had significantly higher harvest indices than the lablab cultivars. This trend was not different when the cultivars were intercropped with early maturing maize cultivar. When intercropped with late maturing maize, indices for ILRI 4612, NAPRI 2 and IT89KD-288 were comparable but lower than for IT99K-241-2 in 2010.

\section{Grain Yield}

Year (Y), cropping system (S) and crop cultivar (C) influenced grain yield (Table 1 ). Mean grain yield was $46.6 \%$ higher in 2010 than in 2011. Intercropping decreased mean grain yield: reduction was higher when legume was intercropped with late maturing maize cultivar $(61 \%)$ than with early maturing maize cultivar (49\%). Cowpea cultivars had higher mean grain yield than lablab cultivars. However, differences did not occur between lablab cultivars or cowpea cultivars for this trait. Significant interactions were recorded for $\mathrm{Y} \times \mathrm{S}, \mathrm{Y} \times \mathrm{C}$ and $\mathrm{Y} \times \mathrm{S} \times \mathrm{C}$ interactions. The interaction between $S$ and $C$ was however, not significant. For the significant $\mathrm{Y} \times \mathrm{S} \times \mathrm{C}$ interaction, in 2010, when sole cropped, lablab cultivars ILRI 4612 and NAPRI 2 and cowpea cultivar IT89KD-288 had similar grain yields (Table 4). The yield of cowpea cultivar IT99-241-2 differed however, from those of lablab cultivars. When intercropped with early maturing maize cultivar, IT99-241-2 had significantly higher grain yield than ILRI 4612 and NAPRI 2. Differences did not occur between IT89KD-288 and IT99-241-2 for this trait. When intercropped with late maturing maize cultivar, grain yield was higher for IT99-241-2 than for the other cultivars. These other cultivars did not differ in grain yield. In 2011, when sole cropped, the lablab cultivars had similar grain yields; the cowpea cultivars also had similar grain yields; but cowpea cultivars had significantly higher grain yields than the lablab cultivars. When intercropped with early maturing maize cultivar, grain yield was variable among all cultivars. Grain yield was higher for IT99-241-2, followed by IT89KD-288, followed by NAPRI 2 and then by ILRI 4612 . When intercropped with late maturing maize cultivar, grain yield was higher for IT89KD-288 than for other cultivars.

\section{Fodder Yield}

There were significant differences between year, among cropping systems and among crop cultivars for fodder yield (Table 1). Mean fodder yield was $20.1 \%$ higher in 2011 than in 2010. Intercropping decreased mean fodder yield: reduction was higher when legume was intercropped with late maturing maize cultivar (47\%) than with early maturing maize cultivar (37\%). Lablab cultivars had higher mean fodder yield than cowpea cultivars. However, differences did not occur between lablab cultivars or cowpea cultivars for this trait. Year $x$ cropping system interaction was not significant. Year $\times$ crop cultivar interaction and the three-way interaction between year, cropping system and crop cultivars were significant (Table 1 ). For the significant $\mathrm{Y} \times \mathrm{S} \times \mathrm{C}$ interaction, in 2010 , when sole cropped, ILRI 4612 had a significantly higher fodder yield than NAPRI 2 (Table 5). There was no significant difference between IT89KD-288 and IT99K-241-2 for this trait. However, lablab cultivars had higher fodder yield than cowpea cultivars. When intercropped with early maturing maize cultivar, there were no differences among crop cultivars. Similarly, when intercropped with late maturing maize cultivar, differences did not occur among crop cultivars. In 2011, when sole cropped, fodder yield did not differ between the lablab cultivars or the cowpea cultivars; but the lablab cultivars produced higher fodder yield than cowpea cultivars. When intercropped with early maturing maize cultivar, fodder yield differed between lablab cultivars but was comparable for cowpea cultivars. Lablab cultivars however, produced significantly higher fodder yield than cowpea cultivars. When intercropped with late maturing maize cultivar, ILRI 4612 produced higher fodder yield than NAPRI 2 but IT89KD-288 and IT99K-241-2 had comparable fodder yields.

\section{Land Equivalent Ratio}

Land equivalent ratios of intercrops of dual-purpose cowpea and lablab with maize cultivars are summarized in Table 6 . Under the different cropping systems, land equivalent ratio varied with crop cultivar. When intercropped with early maturing maize cultivar, intercropping advantage was $35 \%$ for ILRI $4612,32 \%$ for NAPRI $2,25 \%$ for IT89KD-288 and $23 \%$ for IT99K-241-2. When intercropped with late maturing maize cultivar, intercropping advantage was $12 \%$ for ILRI $4612,8 \%$ for NAPRI $2,15 \%$ for IT89KD-288 and $14 \%$ for IT99K-241-2. Mean intercropping advantage was $24 \%$ for ILRI $4612,20 \%$ for NAPRI 2, $20 \%$ for IT89KD-288 and $18 \%$ for IT99K-241-2. Mean intercropping advantage was higher for early maturing maize cultivar $(29 \%)$ than for late maturing maize cultivar (12\%). 


\section{DISCUSSION}

This study focused on the relative performance of sole and intercropped dual-purpose lablab and cowpea with maize of different maturities. Results showed that lablab can grow and produce well under maize as with cowpea. Cropping system and crop cultivar influenced number of pods, harvest index, fodder yield and grain yield of the two legumes. Intercropping cowpea or lablab into early maturing maize cultivar produced a higher number of pods, harvest index, grain yield and fodder yield for the legumes than intercropping into late maturing maize cultivar. The late maturing maize cultivar used in this study was taller and leafier with longer growth period in the field than the early maturing maize cultivar. The longer period of association of the legumes with the late maturing maize cultivar meant longer period of competition for natural resources, lower photosynthetically active radiation transmitted to the understorey legumes and longer stay under maize shade. But with shorter period of association with early maize cultivar, the legumes had some time to compensate for growth and flowering. Similar findings were reported by Santalla et al. (1994) for bush bean in Spain, by Kamara et al. (2011b) for cowpea in Sudan savanna of Nigeria and by Ewansiha et al. (2014b) for cowpea in northern Guinea savanna of Nigeria. In addition, land equivalent ratio showed that intercropping advantage was higher when legumes were intercropped with early maturing maize cultivar than with late maturing maize cultivar. This is because the early maturing maize cultivar improved specie complementarities in time and space, which permitted more growth and reproduction in the legumes before and after its harvest. Thus, for higher lablab or cowpea/maize productivity in intercrop, farmers should intercrop dual-purpose cultivars of these crops with maize of earlier maturities.

The significant year $\times$ cropping system $\times$ crop cultivar interaction recorded for grain yield, number of pods, harvest index and fodder yield suggests that the crop cultivars responded differently to year and cropping system for these traits. This may be due to the fact that cultivars studied involved different legumes under maize of contrasting maturities with yearly variation in rainfall and temperature. Yearly variations in rainfall and temperature have been reported to provide varying environments that affect legumes (Kamara et al., 2011a). The lablab cultivars produced more pods and higher fodder yield than cowpea cultivars in all cropping systems but this did not translate to higher grain yield. This may be due to the fact that lablab was more vigorous and spreading in growth, with more leaves, branches and peduncles that bore more pods. In contrary, cowpea cultivars produced higher grain yield than lablab cultivars in all cropping systems. This may due to the higher harvest index of cowpea cultivars compared to lablab cultivars, meaning that cowpea cultivars had more assimilates transferred to grains than leaves. Moreso, cowpea pods bore higher number of grains with a most likely higher overall grain weight per pod than lablab cultivars. This may be so because the pods of ILRI 4612 and NAPRI 2 are short with 3 to 6 seeds per pod (Ewansiha et al., 2007; Salim et al., 2013). A seed of ILRI 4612 and NAPRI 2 weighs approximately $0.23 \mathrm{~g}$ (Ewansiha, 2002). On the other hand, pods of IT89KD-288 and IT99K-241-2 are longer with about 15 seeds per pod. A seed of cowpea weighs approximately between $0.15-0.19 \mathrm{~g}$ (Kamara et al., 2011a; Aliyu and Makinde, 2016). Thus, for a given area, cowpea is likely to produce higher grain yield than lablab. The harvest index of both lablab and cowpea cultivars were low, a seeming characteristic of dual-purpose herbaceous legumes (Kamara et al., 2011a). These findings show that in crop-livestock systems, dual-purpose cowpea will furnish more grains for humans while dual-purpose lablab will provide more fodder for animals (Ewansiha et al., 2016).

Table 1. Effects of year, cropping system and crop cultivar on performance of dual-purpose lablab and cowpea cultivars in Nigerian northern Guinea savannah.

\begin{tabular}{|c|c|c|c|c|}
\hline Treatment & $\begin{array}{l}\text { Number of } \\
\text { pods (No. } \\
\mathrm{m}^{-2} \text { ) }\end{array}$ & Harvest index & $\begin{array}{l}\text { Grain yield } \\
\left(\mathrm{kg} \mathrm{ha}^{-1}\right)\end{array}$ & $\begin{array}{l}\text { Fodder yield } \\
\left(\mathrm{kg} \mathrm{ha}^{-1}\right)\end{array}$ \\
\hline \multicolumn{5}{|l|}{ Year $(Y)$} \\
\hline 2010 & 123.4 & 0.25 & 848.9 & 2165.2 \\
\hline 2011 & 71.6 & 0.19 & 579.3 & 2601.0 \\
\hline $\operatorname{LSD}(\mathrm{P} \leq 0.05)$ & 6.56 & 0.014 & 34.99 & 136.64 \\
\hline \multicolumn{5}{|c|}{ Cropping system (S)† } \\
\hline Sole & 154.4 & 0.25 & 1125.6 & 3315.8 \\
\hline IC1 & 74.4 & 0.22 & 575.7 & 2075.4 \\
\hline IC2 & 63.9 & 0.20 & 441.0 & 1758.2 \\
\hline $\operatorname{LSD}(P \leq 0.05)$ & 8.04 & 0.026 & 42.86 & 167.35 \\
\hline \multicolumn{5}{|c|}{ Crop cultivar (C) } \\
\hline ILRI 4612 & 114.2 & 0.16 & 587.8 & 3042.3 \\
\hline NAPRI 2 & 113.5 & 0.17 & 632.4 & 2968.9 \\
\hline IT89KD-288 & 81.5 & 0.29 & 802.3 & 1795.9 \\
\hline IT99K-241-2 & 81.1 & 0.29 & 833.9 & 1725.4 \\
\hline $\operatorname{LSD}(P \leq 0.05)$ & 8.69 & 0.028 & 49.33 & 193.24 \\
\hline \multicolumn{5}{|l|}{ Interactions } \\
\hline $\mathrm{Y} \times \mathrm{S}$ & $<.0001$ & 0.0011 & 0.0023 & 0.9812 \\
\hline $\mathrm{Y} \times \mathrm{C}$ & $<.0001$ & $<.0001$ & $<.0001$ & $<.0001$ \\
\hline $\mathrm{S} \times \mathrm{C}$ & 0.0419 & 0.2633 & 0.1362 & $<.0001$ \\
\hline $\mathrm{Y} \times \mathrm{S} \times \mathrm{C}$ & 0.0382 & 0.0449 & 0.0118 & 0.0042 \\
\hline
\end{tabular}


Bajopas Volume 10 Number 2 December, 2017

Table 2. Number of pods of dual-purpose lablab and cowpea grown as sole and as intercrop with maize of contrasting maturities in Nigerian northern Guinea savannah.

\begin{tabular}{|c|c|c|c|c|c|c|c|c|}
\hline \multirow[b]{3}{*}{ Crop cultivar (C) } & \multicolumn{4}{|c|}{2010} & \multicolumn{4}{|c|}{2011} \\
\hline & \multicolumn{8}{|c|}{ Cropping system (S)† } \\
\hline & Sole & IC1 & IC2 & Mean & Sole & IC1 & IC2 & Mean \\
\hline & \multicolumn{8}{|c|}{ No. $m^{-2}$} \\
\hline ILRI 4612 & 251.7 & 117.1 & 106.4 & 158.4 & 114.8 & 54.9 & 40.2 & 69.9 \\
\hline NAPRI 2 & 221.5 & 120.3 & 112.0 & 151.3 & 116.5 & 66.0 & 44.6 & 75.7 \\
\hline IT89KD-288 & 146.6 & 61.3 & 64.6 & 90.8 & 117.2 & 50.4 & 48.5 & 72.1 \\
\hline IT99K-241-2 & 150.0 & 66.5 & 63.1 & 93.2 & 116.4 & 58.9 & 31.5 & 68.9 \\
\hline Mean & 192.5 & 91.3 & 86.5 & & 116.2 & 57.5 & 41.2 & \\
\hline LSD S & 8.04 & & & & & & & \\
\hline LSD C & 8.69 & & & & & & & \\
\hline $\mathrm{LSD} \mathrm{S} \times \mathrm{C}$ & 15.06 & & & & & & & \\
\hline $\operatorname{LSD} Y \times S \times C$ & 21.30 & & & & & & & \\
\hline
\end{tabular}

tSole, sole legume, IC1, intercrop with early maturing maize, IC2, intercrop with late maturing maize

Table 3. Harvest index of dual-purpose lablab and cowpea grown as sole crop and as intercrop with maize of contrasting maturities in Nigerian northern Guinea savannah.

\begin{tabular}{|c|c|c|c|c|c|c|c|c|}
\hline & & & & & \multirow{2}{*}{\multicolumn{4}{|c|}{2011}} \\
\hline \multirow[b]{3}{*}{ Crop cultivar (C ) } & \multicolumn{4}{|c|}{2010} & & & & \\
\hline & \multicolumn{8}{|c|}{ Cropping system $(\mathrm{S}) \dagger$} \\
\hline & Sole & IC1 & IC2 & Mean & Sole & IC1 & IC2 & Mean \\
\hline ILRI 4612 & 0.23 & 0.21 & 0.22 & 0.22 & 0.12 & 0.09 & 0.05 & 0.09 \\
\hline NAPRI 2 & 0.25 & 0.22 & 0.23 & 0.23 & 0.13 & 0.10 & 0.08 & 0.1 \\
\hline IT89KD-288 & 0.32 & 0.29 & 0.23 & 0.28 & 0.34 & 0.28 & 0.25 & 0.29 \\
\hline IT99K-241-2 & 0.33 & 0.27 & 0.32 & 0.3 & 0.35 & 0.28 & 0.21 & 0.28 \\
\hline Mean & 0.27 & 0.24 & 0.25 & & 0.23 & 0.19 & 0.15 & \\
\hline LSD S & 0.026 & & & & & & & \\
\hline LSD C & 0.028 & & & & & & & \\
\hline $\mathrm{LSD} \mathrm{S} \times \mathrm{C}$ & 0.048 & & & & & & & \\
\hline $\mathrm{LSD} Y \times \mathrm{S} \times \mathrm{C}$ & 0.068 & & & & & & & \\
\hline
\end{tabular}

tSole, sole legume, IC1, intercrop with early maturing maize, IC2, intercrop with late maturing maize

Table 4. Grain yield of dual-purpose cowpea and lablab grown as sole crop and as intercrop with maize of contrasting maturities in Nigerian northern Guinea savannah.

\begin{tabular}{|c|c|c|c|c|c|c|c|c|}
\hline \multirow[b]{3}{*}{ Crop cultivar (C) } & \multicolumn{4}{|c|}{2010} & \multicolumn{4}{|c|}{2011} \\
\hline & \multicolumn{8}{|c|}{ Cropping system (S)† } \\
\hline & Sole & IC1 & IC2 & Mean & Sole & IC1 & IC2 & Mean \\
\hline & \multicolumn{8}{|c|}{$\mathrm{kg} / \mathrm{ha}$} \\
\hline ILRI 4612 & 1245.2 & 593.9 & 516.7 & 785.3 & 721.7 & 280.8 & 168.6 & 390.4 \\
\hline NAPRI 2 & 1219.5 & 610.0 & 550.0 & 793.2 & 779.4 & 421.9 & 213.7 & 471.7 \\
\hline IT89KD-288 & 1319.1 & 728.2 & 553.7 & 867.0 & 1162.1 & 549.2 & 501.8 & 737.7 \\
\hline IT99K-241-2 & 1404.6 & 746.3 & 700.3 & 950.4 & 1153.4 & 675.5 & 323.1 & 717.3 \\
\hline Mean & 1297.1 & 669.6 & 580.2 & & 954.2 & 481.9 & 301.8 & \\
\hline LSD S & 42.86 & & & & & & & \\
\hline LSD C & 49.33 & & & & & & & \\
\hline LSD $\mathrm{S} \times \mathrm{C}$ & 85.45 & & & & & & & \\
\hline $\mathrm{LSD} Y \times \mathrm{S} \times \mathrm{C}$ & 120.84 & & & & & & & \\
\hline
\end{tabular}


Bajopas Volume 10 Number 2 December, 2017

Table 5. Fodder yield of dual-purpose cowpea and lablab grown as sole crop and as intercrop with maize of contrasting maturities in Nigerian northern Guinea savannah.

\begin{tabular}{|c|c|c|c|c|c|c|c|c|}
\hline \multirow[b]{3}{*}{ Crop cultivar (C ) } & \multicolumn{4}{|c|}{2010} & \multicolumn{4}{|c|}{2011} \\
\hline & \multicolumn{8}{|c|}{ Cropping system $(\mathrm{S}) \dagger$} \\
\hline & Sole & IC1 & IC2 & Mean & Sole & IC1 & IC2 & Mean \\
\hline & \multicolumn{8}{|c|}{$\mathrm{kg} / \mathrm{ha}$} \\
\hline ILRI 4612 & 3784.8 & 2019.8 & 1561.7 & 2455.4 & 5029.3 & 2833.3 & 3025.0 & 3629.2 \\
\hline NAPRI 2 & 3266.3 & 1900.3 & 1620.3 & 2262.3 & 5118.2 & 3591.7 & 2316.7 & 3675.5 \\
\hline IT89KD-288 & 2769.9 & 1675.0 & 1700.0 & 2048.3 & 1997.0 & 1233.3 & 1400.0 & 1543.5 \\
\hline IT99K-241-2 & 2551. & 1816.7 & 1316.7 & 1894.8 & 2009.6 & 1533.3 & 1125.0 & 1556.0 \\
\hline Mean & 3093.0 & 1853.0 & 1549.7 & & 3538.5 & 2297.9 & 1966.7 & \\
\hline LSD S & 167.35 & & & & & & & \\
\hline LSD C & 193.24 & & & & & & & \\
\hline LSD $\mathrm{S} \times \mathrm{C}$ & 334.70 & & & & & & & \\
\hline $\mathrm{LSD} Y \times \mathrm{S} \times \mathrm{C}$ & 473.34 & & & & & & & \\
\hline
\end{tabular}

tSole, sole legume, IC1, intercrop with early maturing maize, IC2, intercrop with late maturing maize

Table 6. Land equivalent ratio of intercrops of dual-purpose cowpea and lablab with maize of contrasting maturities in Nigerian northern Guinea savannah.

\begin{tabular}{llll}
\hline Crop cultivar & IC1 $^{\dagger}$ & IC2 & Mean \\
\hline I4612 & 1.35 & 1.12 & 1.24 \\
NAPRI2 & 1.32 & 1.08 & 1.20 \\
IT89KD-288 & 1.25 & 1.15 & 1.20 \\
IT99K-241-2 & 1.23 & 1.14 & 1.18 \\
Mean & 1.29 & 1.12 & 1.21 \\
\hline
\end{tabular}

† IC1, intercrop with early maturing maize, IC2, intercrop with late maturing maize

\section{CONCLUSION}

Cropping system and crop cultivar influenced number of pods, harvest index, fodder yield and grain yield of lablab and cowpea. Intercropping the two legumes with maize of contrasting maturities reduced the number of pods, harvest index, fodder yield and grain yield of the legumes. Reduction in these traits was greater under late maize cultivar relative to early maize cultivar. Lablab cultivars had higher number of pods and fodder yield whereas cowpea cultivars had higher harvest index and grain yield. Land equivalent ratio showed that intercropping advantage was higher when the lablab and cowpea were intercropped with early maturing maize cultivar than with late maturing maize cultivar. Performance in all traits depended on year of cultivation, cropping system and crop cultivar. It is recommended that for higher lablab or cowpea/maize productivity in an intercrop, farmers

\section{REFERENCES}

Ajeigbe, H.A., T.O. Oseni, and B.B. Singh (2006). Effect of planting pattern, crop cultivar and insecticide on the productivity of cowpeacereal systems in northern Guinea savanna of Nigeria. Journal of Food, Agriculture and Environment 4: 145-150. should intercrop dual-purpose cultivars of these crops with maize of earlier maturities.

\section{Contribution of Authors}

Chiezey U.F. initiated and facilitated the provision of the land on which the experiment was conducted. Law-Ogbomo K.E. constructed the tables and provided the references. Ewansiha S.U. conducted the field experiment, carried out the data analysis and prepared the manuscript.

\section{Conflict of Interest}

There are no conflicts of interest among the authors, between the authors and any other person/institution where the study was carried out.

\section{Acknowledgements}

The authors would like to thank the Institute for Agricultural Research (IAR), Ahmadu Bello University, Zaria, for providing research field for the trial.

Aliyu, O.M. and B.O Makinde (2016). Phenotypic analysis of seed yield and yield components in cowpea (Vigna unguiculata L., Walp). Plant Breeding and Biotechnology, 4(2):252-261. http://dx.doi.org/10.9787/PBB.2016.4.2.25 $\underline{2}$ 
Altieri MA (1999). The ecological role of biodiversity in agroecosystems. Agriculture, Ecosystem and Environment, 74:19-31

Bedoussac, $L$ and $E$. Justes (2010). The efficiency of a durum wheat-winter pea intercrop to improve yield and wheat grain protein concentration depends on $\mathrm{N}$ availability during early growth. Plant Soil 330:19-35.

Baker, E.F.I. (1974). Mixed cropping with cereals- a system for improvement. In: J.J. Kramer (ed.), International workshop on farming systems, International Crop Research Institute for Semi-Arid Tropics (ICRISAT), 18-21 November 1974, Hyderabad, India, pp 287-301.

Ewansiha, S.U. (2002). Evaluation of Lablab purpureus (I.) sweet for crop and forage production potential at Samaru in the northern Guinea savanna of Nigeria. An unpublished MSc thesis. Ahmadu Bello University, Samaru, Zaria, Nigeria. 128pp.

Ewansiha, S.U., U.F., Chiezey, S.A. Tarawali and E.N.O. Iwuafor (2007). Potential of Lablab purpureus accessions for crop-livestock production in the West African savanna. Journal of Agricultural Science, 145: 229238. doi:10.1017/S0021859606006599.

Ewansiha, S.U., A.Y. Kamara , U.F. Chiezey and J.E. Onyibe (2014a). Agronomic responses of diverse cowpea cultivars to planting date and cropping system. Tropical Agriculture (Trinidad), 91 (2):116-130.

Ewansiha, S.U., A.Y. Kamara, and J.E. Onyibe (2014b). Performance of cowpea cultivars when grown as an intercrop with maize of contrasting maturities. Archives of Agronomy and Soil Science, 60 (5):597-608.

Ewansiha, S.U., S.A. Ogedegbe and U.F. Chiezey (2016). Relative yields of dual-purpose lablab and cowpea when intercropped with maize. Legume Perspectives, Issue13:2 pages.

Hauggaard-Nielsen, H, and E. Jensen (2001). Evaluating pea and barley cultivars for complementarity in intercropping at different levels of soil $\mathrm{N}$ availability. Field Crop Research, 72:185-196

IITA (1983). Annual report. International Institute of Tropical Agriculture, Ibadan, Nigeria.

IITA (2009). Crops [Internet]. Nigeria: International Institute of Tropical Agriculture; [accessed Dec 26 2014]. Available from: http://www.iita.org.

Jagtap, S. (1995). Environmental characterization of the moist lowland savanna of Africa. In: Kang, B.T., Akobundu, I.O, Manyong, V.M., Carsky, R.J., Sanginga, N. and Kueneman E.A. (eds.). Moist savannas of Africa: potentials and constraints for crop production. Proceedings of an international workshop, International Institute of Tropical Agriculture (IITA). pp9-30

Kamara, A.Y., H. Tefera, S.U. Ewansiha, H.A. Ajeigbe, R. Okechukwu, O. Boukar, and L.O. Omoigui (2011a).Genetic gain in yield and agronomic characteristics of cowpea cultivars developed in the Sudan savannas of Nigeria over the past three decades. Crop Science, 51:1877-1866.

Kamara, A.Y., L.O. Omoigui, S.U. Ewansiha, F. Ekeleme, D. Chikoye and $\mathrm{H}$. Ajeigbe (2011b). Performance of semi-determinate and indeterminate cowpeas relay-cropped into maize in Northeast Nigeria. African Journal of Agricultural Research Vol. 6(7), pp. 1763-1770. Available online at http://www.academicjournals.org/AJAR. DOI: $10.5897 / A J A R 10.344$

Kimaro, A.A., V.R., Timmer, S.A.O, Chamshama, Y.N., Ngaga and D.A. Kimaro (2009). Competition between maize and pigeon pea in semi-arid Tanzania: Effect on yields and nutrition of crops. Agriculture, Ecosystem and Environment, 78:115-125.

Kurata, T. (1986). A study on farming system in USSA. Quarterly Journal of Agricultural Ecology 26: 179-205.

Kowal, J.M. and Kassam, A.H. (1978) Agricultural ecology of savanna. Oxford University Press, London. 403pp.

Mead, R. and R.W. Willey (1980). The concept of a land equivalent ratio and advantages in yields from intercropping. Experimental Agriculture, 16:217-228.

Ofori, F. and W.R. Stern (1987). Cereal-legume intercropping systems. Advances in Agronomy 41: 41-49.

Okigbo, B.N. and D.J. Greenland (1976). Intercropping systems in tropical Africa. In: R.I. Papendick, A. Sanchez and G.B. Triplett (eds), Multiple cropping, pp 63101. ASA Special Publication 27, Madison, WI, USA.

Rao, M.R. and M.N. Mathuva (2000). Legumes for improving maize yields and income in semi-arid Kenya. Agriculture, Ecosystem and Environment, 78:123-137.

Salim, M., S. Hossain, S. Alam, J. A. Rashid and S. Islam (2013). Estimation of genetic divergence in lablab bean (Lablab purpureus L.) genotypes. Bangladesh Journal of Agricultural Research, 38(1): 105-114.

Santalla, M., A.M. de Ron and M.R. Escribano (1994). Effect of intercropping bush bean populations with maize on agronomic and their implications for selection. Field Crops Research. 36 (3): 185-189.

SAS Institute Inc. (2011). The SAS system for Windows. Release 9.2. Cary (NC): SAS Institute.

Vandermeer, J.H. (1990). Intercropping. In: Carroll, C.R, J.H. Vandermeer and P.M. Rosset (eds), Agroecology. McGraw-Hill, New York, pp 481-516.

Willey, R.W. (1979). Intercropping-its importance and research needs. Part 1 . Competition and yield advantages. Field Crop Abstracts, 32:1-10. 